\title{
Respon Pemberian Pakan Maggot Black Solder Fly (Hermetia Illucens) Terhadap Kualitas Karkas dan Non Karkas Ayam Kampung Super
}

\author{
Andi Tenri Bau Astuti ${ }^{*}$, Santi, Muhammad Arfan \\ Program Studi Peternakan Fakultas Ilmu Pertanian Universitas Al Asyariah Mandar \\ *Email : anditenribauastut@gmail.com
}

\begin{abstract}
Abstrak
Penelitian ini bertujuan untuk mengetahui pengaruh pakan maggot lalat tentatra hitam (Hermetia illucens) terhadap bobot karkas dan non karkas ayam kampong super. Penelitian dilaksanakan di Mini Ranch Program Study Peternakan UNASMAN. Penelitian ini menggunakan Rancangan Acak Lengkap (RAL) yang terdiri 3 perlakuan pakan yaitu P1 = jagung giling 70\% + pakan komersil 30\%; P2 = jagung giling $70 \%$ + pakan komersil 20\% + maggot 10\%; dan P3 = jagung giling 70\% + maggot 30, dengan 3 ulangan. Hasil penelitian menunjukkan penggunaan pakan maggot dengan level yang berbeda perpengaruh nyata $(\mathrm{P}<0,05)$ terhadap bobot badan, akan tetapi tidak berbeda nyata $(\mathrm{P}>0,05)$ terhadap bobot bagian-bagian karkas dan non karkas. Kesimpulan adalah pemberian pakan maggot dapat meningkatkan bobot karkas dan bobot non karkas yang rendah.
\end{abstract}

Kata Kunci : ayam kampung super, maggot BSF, karkas, non karkas

\section{Pendahuluan}

Pangan hewani merupakan sumber protein yang kandungan asam amino lengkap dan tinggi dibandingkan dengan sumber pangan lain. Pangan hewan secara garis besar terbagi atas dua yaitu daging merah (red meat) dan daging putih (white meat). Minat komsumsi masyarakat Indonesia cenderung pada daging putih ( hite meat ) yaitu daging broiler dan ayam di sebabkan harga terjangkau. Kualitas karkas daging ayam kampung lebih bagus dibandingkan daging broiler karena lebih gurih. Oleh karena itu, komsumsi ayam kampung terus meningkat dari tahun ketahun.

Usaha ternak ayam kampung memiliki peluang cukup tinggi, namun pertumbuhannya yang sangat lambat. Oleh karena itu, peternak memelihara ayam kampung super yang kualitas karkas sama ayam kampung, akan tetapi pertumbahannya lebih cepat. Bobot badan pada umur 2 bulan mencapai 1,5 kg (Mulyono dan Raharjo, 2002). Kekurangan ayam kampung super yaitu komsumsi pakan yang lebih tinggi dengan kandugan nutrisi yang seimbang untuk menunjang pertumbuhan lebih cepat ( Ginting, 2015 ).

Pakan yang berkualitas tinggi memiliki harga tinggi karena harga bahan pakan yang terus meningkat terutama bahan pakan sumber protein karena bersaing dengan komsumsi manusia. Pakan berperan penting dalam kehidupan pokok, pakan yang rendah protein menyebabkan pertumbuhan terganggu karena protein merupakan bahan utama pembentukan karkas ( Hossain, et al., 2013 ).

Larva lalat tentara hitam (BSF) (Hermetia illucens) mengandung kadar protein kasar 42,1\% (Oliver, 2000). Larva BSF harga murah, ramah lingkungan, mudah dikembangbiakkan dan ketersediaannya berkesinambugan. Oleh karena itu, penelitian ini pemeliharaan ayam kampung super dengan menggunakan pakan sumber protein dari larva BSF untuk meperbaiki kualitas karkas.

\section{Metode Penelitian}

Penelitian ini telah dilaksanakan pada bulan Juli hingga September 2019 bertempat di Mini Ranch. Program Studi Peternakan, Fakultas Ilmu Pertanian Universitas Al asyariah Mandar.

Alat yang digunakan yaitu kandang pemeliharaan, pisau, tempat pakan, tempat minum, dan timbangan digital. Sedangkan Bahan yang digunakan yaitu ayam kampung super, maggot, jagung, giling, dan pakan komersil.

Prosedur penelitian yaitu Penelitian ini menggunakan 45 ekor ayam kampung super dipelihara dalam kandang dengan system perkandangan intensif, dengan ukuran $1 \mathrm{~m} \times 1,5$. masing-masing unit kandang diisi oleh 5 ekor ayam kampung super. Setiap kandang dilengkapi tempat minum, tempat makan dan lampu. Ayam kampung super dipelihara 9 minggu. 4 minngu masa adaptasi dan 5 minggu perlakuan.

Pakan diberikan dua kali sehari yaitu pada jam 08.00 dan 16.00 WITA dan air minum diberikan secara adlibitum. Setiap perlakuan diberikan satu jenis pakan, sisa pakan dan minuman diukur setiap minggu selama perlakuan dan umur 9 hari dilakukan pemotongan untuk pengukuran bobot karkas dan non karkas.

Penelitian ini dirancang dengan menggunakan metode RAL dengan 3 perlakuan 3 ulangan. Unit kandang menjadi ulangan dan pakan sebagai ulangan. Setiap perlakuan terdiri dari 3 kandang sehingga total jumlah kandang yaitu 9 unit. Perlakuan pada penelitian ini yaitu jenis pakan sebagai berikut :

P1 = Jagung Giling $70 \%+30 \%$ Pakan Komersil 


$$
\begin{aligned}
& \text { P2 = Jagung Giling } 70 \%+20 \% \text { Pakan Komersil }+10 \\
& \% \text { Maggot } \\
& \text { P3 = Jagung Giling } 70 \%+30 \% \text { Maggot }
\end{aligned}
$$

Data yang diperoleh dianalisis sidik ragam, selanjutnya apabilah perlakuan menunjukkan pengaruh yang nyata, maka dilanjutkan dengan Uji Duncan dengan menggunakan SPSS 22.

\section{Hasil dan Pembahasan}

\subsection{Karkas}

Rataan bobot potong dan bobot karkas pada ayam kampung super ( bobot paha bawah, paha atas, bobot dada, bobot punggung, bobot sayap, bobot leher) disajikan pada tabel 1 .

Tabel 1 Bobot Karkas Pada Ayam Kampung Super yang Diberi Pakan Magot

\begin{tabular}{cccc}
\hline \multirow{3}{*}{ Parameter } & \multicolumn{4}{c}{ Perlakuan (gram) } \\
\cline { 2 - 4 } & $\mathrm{P} 1$ & $\mathrm{P} 2$ & $\mathrm{P} 3$ \\
\hline
\end{tabular}

Bobot potong $\quad 1096.67^{\mathrm{a}} \pm 60.001000 .00^{\mathrm{ab}} \pm 39.28939 .67^{\mathrm{b}} \pm 46.19$

$\begin{array}{llll}\text { paha bawah } \quad 98.67 \pm 98.60 & 98.33 \pm 9.451 & 83.33 \pm 27.68\end{array}$

Paha atas $\quad 90.00 \pm 4.36 \quad 105.00 \pm 4.58 \quad 77.67 \pm 42.91$

$\begin{array}{llll}\text { Bobot dada } & 164.67 \pm 11.50 & 157.33 \pm 16.50 & 135.00 \pm 60.32\end{array}$

Bobot

$\begin{array}{llll}\text { punggung } \quad 114.67 \pm 43.54 & 110.67 \pm 39.576 & 111.00 \pm 5.57\end{array}$

Bobot sayap $\quad 90.00 \pm 4.359 \quad 105.00 \pm 4.58 \quad 77.67 \pm 42.91$

Bobot leher $\quad 42.33 \pm 12.288 \quad 43.00 \pm 12.2882141 .333 \pm 11.1504$

Keterangan: Huruf yang Berbeda pada Superscript Angka RataRata, Berbeda Nyata $(\mathrm{P}<0.05)$

Hasil analisis varians menunjukkan pemberian pakan maggot pada level yang berbeda perpengaruh nyata $(\mathrm{P}<0.05)$ pada bobot potong ayam, akan tetapi tidak berbeda dengan bobot bagian-bagian karkas (paha bawah, paha atas, bobot dada, bobot punggung, bobot sayap, bobot leher) pada ayam kampung super.

Hasil analisis uji Duncan pada bobot potong ayam kampung super yang diberi pakan magot dengan level yang berbeda menunjukkan perlakuan P1 (1096.67 g) berbeda nyata lebih besar dari P3(939.67 g), akan tetapi tidak berbeda dengan P2 (1000 g). Perlakuan P2 tidak berbeda nyata dari perlakuan P3.

Tingginya bobot potong pada perlakuan P1 dibandingkan perlakuan lain, dikarenakan tingginya konsumsi pakan dan kadar protein yang tinggi. Hal ini sesuai dengan pendapat Winedar dkk.,(2006) bahwa pertambahan bobot badan disebabkan secara langsung oleh ketersediaan asam amino pembentuk jaringan sehingga konsumsi protein pakan berhubungan langsung dengan proses pertumbuhan, oleh karena itu sangat memerlukan perhatian khusus mengenai manajemen penggunaan bahan pakan yang mengandung protein yang cukup sesuai dengan kebutuhan broiler untuk memenuhi asupan asam amino yang dibutuhkan oleh tubuh.

Bobot bagian-bagian karkas yang paling tinggi pada perlakuan P1 (bobot paha bawah 98.67, bobot dada 164.667, bobot punggung 114.67 ) dan P2 ( paha atas
105.00, bobot sayap 105.00, bobo leher 43.00 ). Tingginya bobot karkas pada P1 di sebabkan oleh bobot potong tinggi. Hal ini sesuai dengan pendapat North dan Bell (1992) bahwa persentase karkas broiler bervariasi antara $65-75 \%$ dari bobot badan, semakin berat ayam yang dipotong, maka karkasnya semakin tinggi pula.

\subsection{Non Karkas}

Rerataan bobot non karkas ( hati, kepala, kaki, usus besar, dan ampela ) pada ayam kampung super yang diberi pakan maggot dengan level yang berbeda, di sajikan pada table di bawah.

Tabel 2 Bobot Non Karkas pada Ayam Kampung Super yang Diberi Pakan Magot

\begin{tabular}{lccc}
\hline \multirow{2}{*}{ Parameter } & \multicolumn{3}{c}{ Perlakuan (gram) } \\
\cline { 2 - 4 } & $\mathrm{P} 1$ & $\mathrm{P} 2$ & $\mathrm{P} 3$ \\
\hline Bobot hati & $29.33 \pm 2.08$ & $21.33 \pm 4.72$ & $21.67 \pm 3.21$ \\
Bobot kepala & $47.67 \pm 2.89$ & $49.00 \pm 3.46$ & $45.00 \pm 4.36$ \\
Bobot kaki & $65.00 \pm 3.00$ & $61.33 \pm 7.23$ & $56.33 \pm 7.23$ \\
B.usus besar & $12.67 \pm 4.51$ & $10.33 \pm 4.62$ & $12.33 \pm 2.89$ \\
Bobot ampela & $55.67 \pm 7.23$ & $58.67 \pm 5.13$ & $51.67 \pm 2.08$ \\
\hline
\end{tabular}

Bobot non karkas pada P1 cenderung lebih tinggi dibandingkan yang lain dan terendah yaitu P3. Bobot non karkas mempengaruhi kualitas dari karkas. Zaenab, dkk (2005) Karkas ayam dibedakan menjadi karkas kosong yaitu ayam yang telah disembelih dan dikurangi dengan darah, alat tubuh bagian dalam, kepala dan kaki. Adapun karkas segarnya diisi dengan hati, jantung dan rempela yang telah dibersihkan. Rata-rata bobot karkas ayam berkisar antara $65-75 \%$ dari bobot hidup pada waktu siap potong. Persentase bagian-bagian karkas adalah persentase karkas dada sekitar $23,45-25,5 \%$ dan dada merupakan bagian yang banyakmengandung daging, persentase karkas paha sekitar $21,80 \%$, persentase karkas punggung sekitar $20 \%$, dan persentase karkas sayap $8,6 \%$.

\section{Kesimpulan}

Berdasarkan analisa data dapat disimpulkan pemberian apakan maggot BSF signifikan berpengaruh pada bobot potong. Akan tetapi, pada bobot bagian-bagian karkan tidak berbeda, sedangkan bobot bagian - bagian non karkas cenderung lebih ringan pada ayam kampung super.

\section{Daftar Pustaka}

Ginting N, 2015, Manajemen Pemasaran . Bandung : Yrama Widya

Hossain, M.A., A.F. Islam dan P.A. Iji. 2013. Growth responses, excreta quality, nutrient digestibility, bone development and meat yield traits of broiler chickens fed vegetable or animal protein diets. South African J. Anim. Sci. 43 (2) : 208-218.

Mulyono dan Raharjo. 2002. Ayam Jawa Super Postur Negeri Rasa Kampung. Agromedia Pustaka.

North, M. O, and D. D Bell 1992. Cormmcial Chickin Production Manual. Third Edition. Avi Publishing Co, edn, Westport Connecticut. 
Olivier PA. 2000. Larval Bio. Conversion. E- Conferense : Area- Wide Integration OF Specialized Crop and Lifestock Production. 18 Juni. 3 August 2000. http : // Lead. Er., Vurtual Centre. Org /en /ele/ awi 2000 / download. Htm.

Winedar, H., S. Listyawati dan Sutarno. 2006. Daya cerna protein pakan, kandungan protein daging, dan pertambahan bobot badan broiler setelah pemberian pakan yang difermentasi dengan effective microorganisms-4 (EM-4), Bioteknologi 3 (1): 14-19.

Zaenab, A. B Bakrie., T. Ramadhan dan Nasrullah. 2005. Pengaruh Pemberian Jamu Ayam Terhadap Kualitas Karkas Ayam Buras Potong. Laporan Penelitian Balai Pengkajian Teknologi Pertanian Dki Jakarta. 